inOedia $\quad \begin{aligned} & \text { InMedia } \\ & \text { The French Journal of Media Studies }\end{aligned}$

5 | 2014

Media and Diversity

\title{
Film and Television Policies in English-speaking Countries
}

25 October 2013, Université Paris 8 Vincennes-Saint-Denis

\section{Samuel Bréan}

\section{(2) OpenEdition}

\section{Journals}

Electronic version

URL: http://journals.openedition.org/inmedia/809

DOI: $10.4000 /$ inmedia.809

ISSN: 2259-4728

\section{Publisher}

Center for Research on the English-Speaking World (CREW)

\section{Electronic reference}

Samuel Bréan, « Film and Television Policies in English-speaking Countries », InMedia [Online], 5 | 2014, Online since 17 October 2014, connection on 08 September 2020. URL : http://

journals.openedition.org/inmedia/809; DOI : https://doi.org/10.4000/inmedia.809

\footnotetext{
This text was automatically generated on 8 September 2020

(c) InMedia
} 


\section{Film and Television Policies in English-speaking Countries}

25 October 2013, Université Paris 8 Vincennes-Saint-Denis

Samuel Bréan

\section{EDITOR'S NOTE}

Conference organised by Joël Augros, Nathalie Dupont, Nolwenn Mingant and Cecilia Tirtaine

1 This one-day conference was organised by CinEcoSA (Cinéma, Économie \& Sociétés Anglophones - Cinema, Economy in English-Speaking Countries), a research group which brings together academics working on the cinema and television industries of English-speaking countries. ${ }^{1}$ It is part of a new series of events on "Film \& TV Policy" (2013-2014); the first such series organised by this research group was "Film Marketing" (2010-2011). ${ }^{2}$ This conference was itself the second installment in the cycle, after a panel called "Film Policies, Turning Points in Film History" at the 2013 NECS (European Network for Cinema and Media Studies) International Conference in Prague. ${ }^{3}$

2 The conference was divided into four panels: a general panel on "Film Policy Issues" followed by two more specific case studies (Australia, the United Kingdom) and a workshop (Scotland). In the opening panel, Daniel Peltzman (Universite de FrancheComté) looked into the effects that the 2009 Film and Television Tax Credit program had on the California motion picture industry. This measure was created by the State of California to combat runaway productions, both nationally (in other US States) and internationally. Peltzman based his paper on official reports and debates that took place since 2009, especially when opponents of the program asked for hearings about its efficiency, which is indeed questionable: the measure did not put an end to runaway productions and mostly benefited producers, instead of creating new jobs. This paper testified to the existence of an economic war between California, other US States and foreign countries. 
3 Sian Barber (Queen's University, Belfast) presented a paper on another type of state intervention: censorship. Her research focuses on the British Board of Film Classification (BBFC) and draws heavily on archival documents. ${ }^{4}$ Here she looked at an important moment within film legislation in Britain: the introduction of the Video Recordings Act (VRA) of 1984, which granted the BBFC statutory power to certificate videos for viewing in the home, but also made it legally accountable for its decisions. This piece of legislation came at a time when the then new technology of video was shrouded in public controversy about "Video Nasties". Barber shed light on the relationship between the BBFC and the British government, by quoting from Parliamentary debates (where some MPs expressed their doubts about granting power to the BBFC) and BBFC papers. What the VRA ultimately changed, Barber claims, is the power relationship between the BBFC and the film and video industries. The history of film censorship in Britain has always been a fascinating one and Barber's paper gave a fresh and informed insight into one of its key episodes.

4 The final paper of the panel, by Frédéric Gimello (Université d'Avignon), was a more theoretical and analytical one. Gimello used a Foulcaldian framework to question the notion of "quality" as a criterion used in film policies and compared the French and British contexts. He specifically examined the notion of "creativity" as a characteristic privileged by expert committees.

5 The opening panel was varied in its approaches and objects of study. The two "case studies" had one thing in common: they were both presented by scholars who were involved in the institutions they discussed and based their papers on their personal experience, which allowed for a very enlightening approach. Julia Hammett-Jamart (Wollongong University) was the Manager of Governance of Screen Australia and gave a paper on Australian film policy. ${ }^{5}$ Australian cinema came to international prominence in the 1970s, helped by measures designed to kick-start local production. The structures that were put in place then were replaced in 2006. Hammett-Jamart examined the (seemingly positive) effects that these reforms had on the Australian film industry and showed how the issues that were problematic in the 1980s came up again in 2006: what should be funded and how?

6 Roger Shannon (Edge Hill University) shed light on a recent change in the British film industry following the sudden demise in 2011 of the UK Film Council. This restored the British Film Institute (BFI) ${ }^{6}$ as the film industry's lead strategic body for both cultural and commercial interests. Shannon drew on his experience in the north-west of England to discuss the implications of these changes at a regional level.

7 The final panel was on Scotland, with two scholars hailing from the University of St. Andrews. Michael Franklin looked at key changes in film market construction (the "Film Value Chain"), which involves looking at audience response in social media ("Digital Engagement Metrics", DEMs) and defining new roles for the public funder, in this case Scottish Screen/Creative Scotland. Franklin's approach thus involved looking at the production of films, but also at marketing them. His paper was especially interesting in that it opened perspectives for the future. Finally, Fabiola Alvarez looked back at an independent film agency in Scotland, Scottish Screen, which was active between 1997 and 2010 before merging with the Scottish Arts Council. She examined how decisions were made and justified at Scottish Screen by drawing on a theoretical framework laid down by Luc Boltanski and Thévenot; these authors laid down six orders (civic, market, inspired, fame, industrial, and domestic) to define worth. ${ }^{7}$ 
8 This conference, although apparently quite modest in scope, resulted in a rich variety of approaches to, and fruitful interrogations of, film policy. As Nolwenn Mingant noted in her concluding remarks, "film policy is a strongly polemical topic" fraught with tensions. She also remarked that "cinema is about a) creativity, b) (national) culture, c) economics". I would personally add that, being more concerned with the first and second of these, I was a bit curious when I attended the first CinEcoSA conference in 2010, not knowing what to expect. The October 2013 conference proved once more that this approach to cinema allows for rewarding, demanding yet accessible contributions that focus on cinema both as an art and as an industry.

9 The next CinEcoSA conference will take place in late 2014 and invite scholars and professionals to debate the vision and application of film policy around the world.

\section{ENDNOTES}

1. See http://www.cinecosa.com.

2. A selection of papers from this series can be found in issue 3 of InMedia, "Cinema and Marketing: When Cultural Demands Meet Industrial Practices".

3. See http://necs.org.

4. See her Censoring the 1970s: The BBFC and the Decade that Taste Forgot (Newcastle upon Tyne: Cambridge Scholars Publishing, 2011). On the BBFC, see Edward Lamberti (ed.), Behind the Scenes at the BBFC: Film Classification from the Silver Screen to the Digital Age (London: BFI, 2012).

5. I would recommend two Australian online film journals which testify to a strong film culture in that country: Screening the Past (http://www.screeningthepast.com/) and Senses of Cinema (http://sensesofcinema.com/). Related to the subject of film policies are a website keeping track of censorship in Australia (http://www.refused-classification.com/) and a study of film production and the Gold Coast (Ben Goldsmith, Susan Ward and Tom O'Regan, Local Hollywood: Global Film Production and the Gold Coast (Brisbane: University of Queensland Press, 2011)). Finally, for a personal and engrossing testimony on film festivals in Australia, see David Stratton's memoir I Peed on Fellini: Recollections of a Life in Film (Sydney: William Heinemann, 2008).

6. See Geoffrey Nowell-Smith and Christophe Dupin (eds), The British Film Institute, the Government and Film Culture, 1933-2000 (Manchester: Manchester University Press, 2012).

7. See Luc Boltanski and Laurent Thévenot, De la justification. Les économies de la grandeur (Paris: Gallimard, 1991); English translation: On Justification: Economies of Worth, translated by Catherine Porter (Princeton, NJ: Princeton University Press, 2006).

\section{AUTHOR}

\section{SAMUEL BRÉAN}

Translator and independent researcher, member of ATAA (Association des Traducteurs Adaptateurs de l'Audiovisuel) 